\title{
The tylosin producer, Streptomyces fradiae, contains a second valine dehydrogenase
}

\author{
Lieu Thi Nguyen, Kien Trung Nguyen, Jaroslav Sp/žek and \\ Vladislav Běhal
}

Author for correspondence: Vladislav Běhal. Tel: +422 4752350. Fax: +4224715743.

Institute of Microbiology, Academy of Sciences of the Czech Republic, Vídeñská 1083, 14220 Prague 4, Czech Republic

\begin{abstract}
A second NAD-dependent valine dehydrogenase (VDH) of Streptomyces fradiae was detected and purified to homogeneity by affinity chromatography on Reactive-Blue 2 Sepharose followed by gel filtration and Mono $Q$ fast protein liquid chromatography. The relative molecular masses of the native enzyme and its subunits were determined to be 80000 and 41000 , respectively, indicating that the enzyme is a homodimer. The enzyme was the only active VDH in S. fradiae; its activity was significantly induced by L-valine, but was repressed by ammonia. Among branched- and straight-chain amino acids that serve as enzyme substrates, L-2-aminobutyrate and L-valine are preferred. Significant activities were found with deamino-NAD+ and 3-pyridinealdehydeNAD $^{+}$. The molecular and catalytic properties of the enzyme distinguish it from the enzyme previously purified, and thus indirectly indicate the existence of two VDHs in S. fradiae.
\end{abstract}

Keywords: Streptomyces fradiae, valine dehydrogenase, affinity purification

\section{INTRODUCTION}

Valine metabolism in Streptomyces provides an alternative source of $n$-butyrate, 2-methylmalonate and propionate building units of the aglycones of the macrolide antibiotics leucomycin (Omura et al., 1983b) and tylosin (Omura et al., 1983a; Omura \& Tanaka, 1986), and the polyether antibiotics monensin (Pospíśil et al., 1983; Sood et al., 1988) and lasalocid A (Sherman et al., 1986). Valine dehydrogenase (VDH, EC 1.4.1.8), which catalyses the reversible oxidative deamination of branched-chain amino acids yielding the corresponding 2 -keto acids, is the first enzyme of the valine catabolic pathway (Massey et al., 1976; Priestley \& Robinson, 1989; Navarrete et al., 1990). Thus, VDH may be important for the biosynthesis of these antibiotics. Suppression of VDH activity either by elevating ammonium concentration in the fermentation medium (Omura et al., 1983a; Omura \& Tanaka, 1986), or by disrupting the VDH-encoding $v d b$ gene (Hutchinson, 1994), lowers tylosin production in $S$. fradiae. Disruption of $v d b$ also results in a similar effect on spiramycin production in $S$. ambofaciens (Hutchinson, 1994). However, production is restored by adding lower fatty acids such as $n$-butyrate, propionate and acetate to

Abbreviations: FPLC, fast protein liquid chromatography; LDH, leucine dehydrogenase; VDH, valine dehydrogenase. the fermentation medium (Omura \& Tanaka, 1986; Hutchinson, 1994), or by introducing $v d b$ into the $\mathrm{VDH}^{-}$ mutant (Hutchinson, 1994). Since disruption of the $S$. coelicolor $v d b$ gene does not affect production of actinorhodin, an acetate-derived antibiotic (Tang \& Hutchinson, 1993), it has been suggested that valine metabolism is an important source of precursors only for antibiotics that are produced from propionate (Hutchinson, 1994).

VDH is assumed to be the main enzyme responsible for utilization of branched-chain amino acids by Streptomyces because $S$. fradiae mutants that lack VDH activity (Omura et al., 1983a), and $S$. coelicolor mutants with a disrupted $v d b$ gene (Tang \& Hutchinson, 1993), lost the ability to grow with branched-chain amino acids as the sole $\mathrm{N}$ source. $\mathrm{VDH}$ activity was first detected in the tylosin-producing $S$. fradiae (Omura et al., 1983a), and a VDH enzyme with 12 subunits, each of $M_{\mathrm{r}} 18000$, was isolated and characterized (Vančura et al., 1988b). The fact that the $S$. fradiae VDH differs significantly from the tetrameric VDH from S. aureofaciens (Vančurová et al., 1988), and the dimeric VDHs from S. cinnamonensis (Priestley \& Robinson, 1989) and S. coelicolor (Navarrete et al., 1990), prompted us to examine whether $S$. fradiae possessed additional VDHs. In the present work, we have purified a second VDH of $S$. fradiae by affinity chromatography on Reactive-Blue 2 Sepharose. 


\section{METHODS}

Materials. Coenzymes, amino acids, 2-keto acids, buffers and Reactive-Blue 2 Sepharose were purchased from Sigma.

Micro-organism and cultivation conditions. The microorganism used was a sporulating isolate of $S$. fradiae $30 / 3$ (Vančura et al., 1988b). A vegetative inoculum was cultivated for $48 \mathrm{~h}$ in a medium containing $(\%, w / v)$ : glucose, 2.0 ; enzymically hydrolysed casein (IMUNA, Czech Republic), $0.3 ; \mathrm{NaCl}, 0 \cdot 5 ; \mathrm{CaCO}_{3}, 0.3 ; \mathrm{MgSO}_{4} .7 \mathrm{H}_{2} \mathrm{O}, 0.05 ; \mathrm{K}_{2} \mathrm{HPO}_{4}, 0 \cdot 1$; yeast extract, $0 \cdot 1 ;\left(\mathrm{NH}_{4}\right)_{2} \mathrm{SO}_{4}, 0 \cdot 17$. The culture was used as a $5 \%$ $(\mathrm{v} / \mathrm{v})$ inoculum for a medium containing the following minerals $(\%, \mathrm{w} / \mathrm{v}): \mathrm{NaCl}, 0 \cdot 5 ; \mathrm{CaCO}_{3}, 0 \cdot 3 ; \mathrm{MgSO}_{4} .7 \mathrm{H}_{2} \mathrm{O}, 0 \cdot 05 ; \mathrm{K}_{2} \mathrm{HPO}_{4}$, $0 \cdot 1$. One millilitre of a solution of trace elements containing $\mathrm{FeSO}_{4} \cdot 7 \mathrm{H}_{2} \mathrm{O}, \mathrm{MnCl}_{2} .4 \mathrm{H}_{2} \mathrm{O}, \mathrm{ZnSO}_{4} .7 \mathrm{H}_{2} \mathrm{O}, \mathrm{CuSO}_{4} \cdot 5 \mathrm{H}_{2} \mathrm{O}$ and $\mathrm{CoCl}_{2} \cdot 6 \mathrm{H}_{2} \mathrm{O}$ (each of $0 \cdot 1 \%$ ) was added to $1 \mathrm{l}$ of medium. $\mathrm{C}$ and $\mathrm{N}$ sources were sterilized separately and added to the media before inoculation at the final concentrations indicated in the text. The $\mathrm{pH}$ of both media before autoclaving was about $7 \cdot 0$. Cultivation conditions were as previously described (Vančura et al., 1988b).

Purification of VDH2. Except for fast protein liquid chromatography (FPLC), which was performed at $22^{\circ} \mathrm{C}$, all operations were done at $4{ }^{\circ} \mathrm{C}$.

(i) Preparation of crude extracts. Mycelia grown for $72 \mathrm{~h}$ with $25 \mathrm{mM}$ L-valine and $0.3 \%(\mathrm{w} / \mathrm{v})$ enzymically hydrolysed casein as the $\mathrm{N}$ source were harvested by centrifugation at $4000 \mathrm{~g}$ at $4{ }^{\circ} \mathrm{C}$ (4 min), washed once with ice-cold $50 \mathrm{mM}$ Tris $/ \mathrm{HCl}$

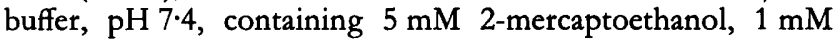
EDTA and $10 \%(\mathrm{v} / \mathrm{v})$ glycerol (buffer A), centrifuged at $20000 \mathrm{~g}$ at $4{ }^{\circ} \mathrm{C}(5 \mathrm{~min})$, and finally stored at $-20^{\circ} \mathrm{C}$. The thawed mycelium ( $15 \mathrm{~g}$, wet weight) was suspended in $50 \mathrm{ml} 50 \mathrm{mM}$ imidazole $/ \mathrm{HCl}$, pH 6.3, containing $5 \mathrm{mM}$ 2-mercaptoethanol, $1 \mathrm{mM}$ EDTA and $10 \%(\mathrm{v} / \mathrm{v})$ glycerol (buffer B), and disrupted by sonication as described elsewhere (Navarrete et al., 1990). Supernatants obtained after centrifugation at $100000 \mathrm{~g}$ at $4{ }^{\circ} \mathrm{C}(45 \mathrm{~min})$ were used as crude extracts.

(ii) Reactive-Blue 2 Sepharose chromatography. The crude extract (70 ml) was recycled overnight at $20 \mathrm{ml} \mathrm{h}^{-1}$ through a ReactiveBlue 2 Sepharose column $(1.6 \times 10 \mathrm{~cm}$, bed volume $20 \mathrm{ml})$ preequilibrated with buffer $B$. The column was washed with $200 \mathrm{ml}$ buffer $B$ and the VDH activity was eluted with $150 \mathrm{ml}$ buffer $\mathrm{C}$ (buffer B, pH 7.5) at $40 \mathrm{ml} \mathrm{h}^{-1}$. Fractions of $3 \mathrm{ml}$ were collected; the volume of the pooled active fractions $(100 \mathrm{ml})$ was reduced to $5 \mathrm{ml}$ by ultrafiltration using a CF25 Amicon membrane (25000 cut off).

(iii) Gel filtration. The concentrated enzyme solution from step 2 ( $5 \mathrm{ml})$ was loaded on a Sephacryl-S300 HR column $(1.6 \times 58 \mathrm{~cm}$, void volume $41 \mathrm{ml}$ ) pre-equilibrated with buffer $D$ (buffer A containing $0.2 \mathrm{M} \mathrm{NaCl}$ ). Proteins were fractionated with the same buffer at $4.2 \mathrm{ml} \mathrm{h}^{-1}$ and $0.5 \mathrm{ml}$ fractions were collected.

(iv) Mono Q FPLC. The pooled active fractions from step $3(6 \mathrm{ml})$

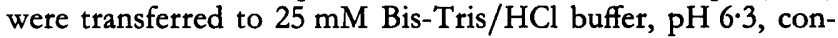
taining $5 \mathrm{mM} 2$-mercaptoethanol, $1 \mathrm{mM}$ EDTA and $10 \%(\mathrm{v} / \mathrm{v})$ glycerol (buffer E) by ultrafiltration as described in step (ii). Six $1 \mathrm{ml}$ samples were loaded on a Mono Q HR5/5 column preequilibrated with buffer $E$. After the column had been washed with $5 \mathrm{ml}$ of the same buffer, proteins were eluted with a linear gradient of $0-40 \%$ buffer $\mathrm{F}$ (buffer $\mathrm{E}$ containing $1 \mathrm{M} \mathrm{NaCl}$ ) at $1 \mathrm{ml} \mathrm{min}{ }^{-1}$ in a total buffer volume of $22 \mathrm{ml}$. Fractions of $0.5 \mathrm{ml}$ were collected. The active fractions were pooled, dialysed overnight against 11 buffer $\mathrm{A}$, and stored at $4^{\circ} \mathrm{C}$.

Enzyme assay. VDH oxidative deamination and reductive amination activities at $30^{\circ} \mathrm{C}$ were determined at $\mathrm{pH} 10.4$ and
$8 \cdot 8$, respectively, with a UV-160A Shimadzu spectrophotometer as previously described by Vančura et al. (1988b). Unless otherwise stated, the enzyme activity was measured in the deamination assay system with $10 \mathrm{mM} \mathrm{L}$-valine as the substrate. Enzyme activity was expressed as nmol NADH formed or consumed per second (nkat). The Michaelis constant $\left(K_{m}\right)$ of the purified enzyme was determined under standard assay conditions from double-reciprocal plots of reaction velocity versus substrate concentration. The plots were drawn using the least squares method from the results of nine measurements. For $K_{\mathrm{m}}$ determinations, concentrations of individual substrates were varied over the following ranges: L-valine, $0 \cdot 2-10 \mathrm{mM}$; $\mathrm{NAD}^{+}, 0.01-1.5 \mathrm{mM}$; 2-ketoisovalerate, $0.1-10 \mathrm{mM} ; \mathrm{NH}_{4}^{+}$, 10-100 mM; NADH, 0.01-0.1 mM. While the concentration of one substrate was changed, the concentrations of the other substrates were maintained at saturation levels (maximum values in the tested concentration ranges).

Analytical methods. Native-PAGE was performed with $6.5 \%$ (w/v) acrylamide gels (Hames, 1981). VDH was detected on native-PAGE gels by the VDH activity staining method (Priestley \& Robinson, 1989). SDS-PAGE was performed with $10 \%$ acrylamide gels (Laemmli, 1970) with the following standards: $\beta$-galactosidase (116000), phosphorylase (97400), BSA (66000), egg albumin (45000), L-lactate dehydrogenase (35000), carbonic anhydrase (29000), chymotrypsinogen (25000) and cytochrome $c(12400)$. Gel filtration was done as described in step (iii) of the enzyme purification protocol; MS II kit proteins (Serva) were used as $M_{\mathrm{r}}$ standards. Protein concentrations were determined by the dye-binding method (Bradford, 1976) with BSA as the standard.

\section{RESULTS}

\section{Detection and regulation of VDH2}

A preliminary experiment with crude extracts of cells grown with $\mathrm{L}$-valine as the sole $\mathrm{N}$ source showed that the deamination activity of the $S$. fradiae $\mathrm{VDH}$ with L-2aminobutyrate was $200 \%$ of that with L-valine. In contrast, the corresponding value for the previously purified VDH (hereafter called VDH1) was only $68.9 \%$ (Vančura et al., 1988b). In addition, the VDH activity in the crude extracts was eluted from a Sephacryl-S300 HR gel filtration column as a single activity peak with an $M_{\mathrm{r}}$ of 80000 , whereas the $M_{\mathrm{r}}$ of VDH1 was 215000 . We used $\mathrm{VDH}$ activity staining to detect isozymes on nativePAGE gels. Only one VDH was found in crude extracts of $S$. fradiae cells grown with several $C$ and $N$ sources (Fig. 1a). A NAD oxidase that oxidized $\mathrm{NAD}^{+}$in the absence of $\mathrm{L}$-valine was also detected. Since the VDH detected differed significantly in molecular and catalytic properties from VDH1 previously purified from $S$. fradiae (see below), it was called VDH2.

We measured VDH activity in $72 \mathrm{~h} S$. fradiae cells, which were exponentially grown in chemically defined medium (Vančura et al., 1989). The results showed that with glucose as the $C$ source, the enzyme activity was induced by $25 \mathrm{mM}$ L-valine $\left(1.64 \mathrm{nkat} \mathrm{mg}^{-1}\right)$ but strongly repressed by 25,50 or $100 \mathrm{mM}$ ammonia $\left(0.05-0.06 \mathrm{nkat} \mathrm{mg}^{-1}\right)$. However, in the presence of $25 \mathrm{mM}$ valine, the repressive effect of $25 \mathrm{mM}$ ammonium

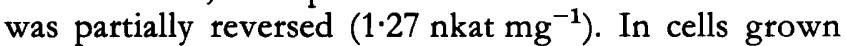
with $100 \mathrm{mM}$ valine as both the $C$ and the $\mathrm{N}$ source, and in cells grown with $1 \%(\mathrm{v} / \mathrm{v})$ glycerol (C source) and 
(a)

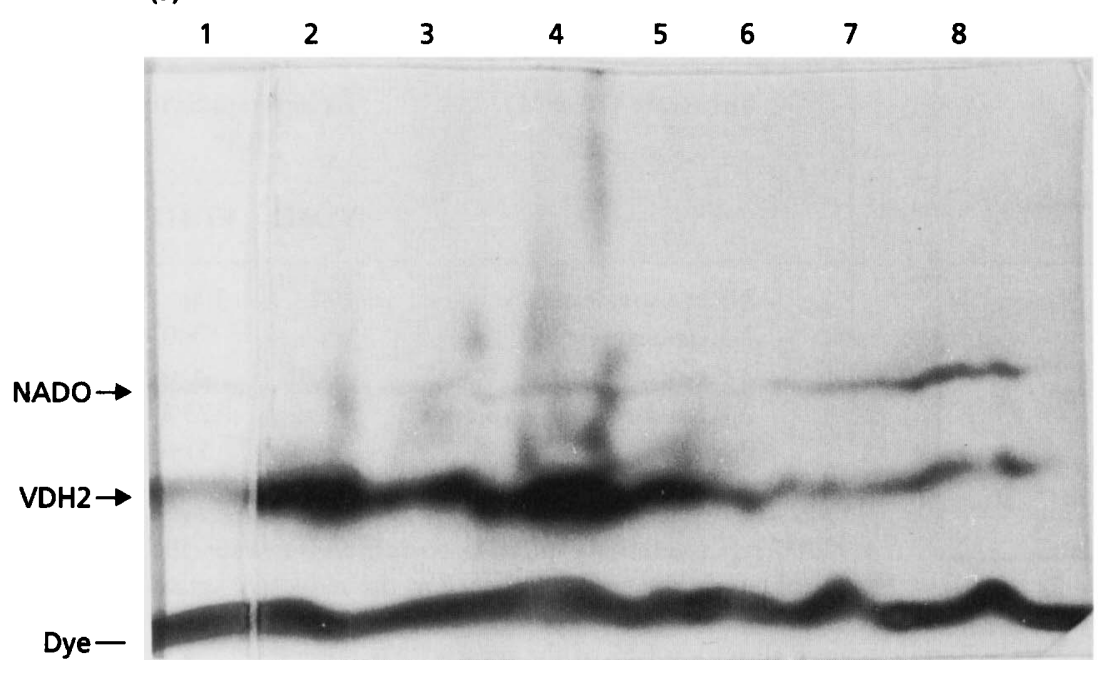

(b)

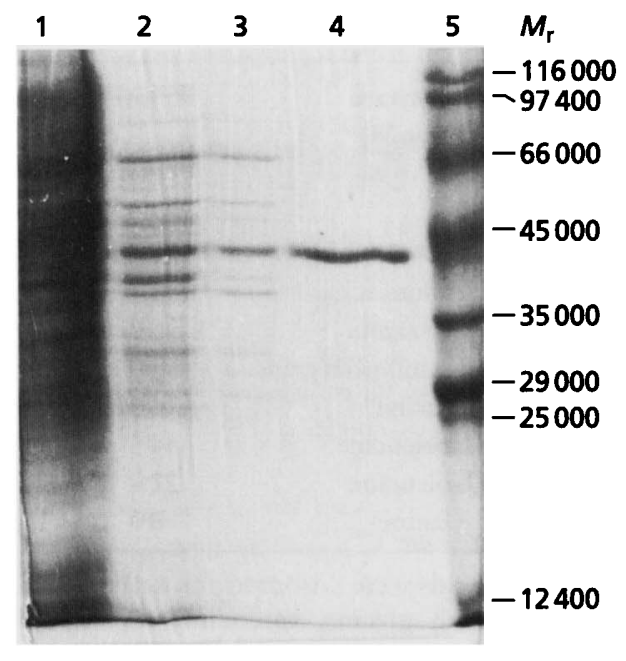

Fig. 1. (a) Native-PAGE of extracted proteins from $S$. fradiae. Crude extract $(25 \mu \mathrm{l})$ was loaded in each lane. Cells were grown for $72 \mathrm{~h}$ with $2 \%(\mathrm{w} / \mathrm{v})$ glucose (C source) and the following N sources: $25 \mathrm{mM}$ valine (lanes 1 and 4 ); $25 \mathrm{mM}$ valine + $25 \mathrm{mM}$ ammonium (lane 2); $25 \mathrm{mM}$ ammonium (lane 6); $50 \mathrm{mM}$ ammonium (lane 7); $100 \mathrm{mM}$ ammonium (lane 8). Cells were also grown with $1 \%(\mathrm{v} / \mathrm{v})$ glycerol (C source) and $25 \mathrm{mM}$ valine ( $\mathrm{N}$ source) (lane 3), or with $100 \mathrm{mM}$ valine (as both the $\mathrm{C}$ and the $\mathrm{N}$ source) (lane 5). The gel was stained for VDH activity with L-valine (lanes 2 to 8 ) or without Lvaline as control (lane 1). Positions of VDH2, NAD oxidase (NADO) and the dye marker are indicated on the left. The basal VDH activity in lane 1 is probably due to the residual L-valine in the crude extract. Similar activity intensities of the NADoxidase were observed when the gels were stained with or without L-valine (lane 1, and data not shown). (b) SDS-PAGE of proteins after individual purification steps. Lane 1, crude extract; lane 2, Reactive Blue 2 fraction; lane 3, gel filtration fraction; lane 4, purified VDH2 after Mono Q FPLC; lane 5, standard $M_{r}$ markers are indicated on the right. The gel was stained with Coomassie Blue R-250.

Table 1. Purification of VDH2 from S. fradiae

\begin{tabular}{|c|c|c|c|c|c|}
\hline Purification step* & $\begin{array}{c}\text { Total } \\
\text { protein } \\
(\mathrm{mg})\end{array}$ & $\begin{array}{c}\text { Total } \\
\text { act. } \\
\text { (nkat) }\end{array}$ & $\begin{array}{c}\text { Sp. act. } \dagger \\
\text { (nkat } \\
\text { mg }^{-1} \text { ) }\end{array}$ & $\begin{array}{c}\text { Recovery } \\
(\%)\end{array}$ & $\begin{array}{c}\text { Purification } \\
\text { (-fold) }\end{array}$ \\
\hline (i) Crude extract & $185 \cdot 0$ & $174 \cdot 0$ & 0.94 & 100 & 1 \\
\hline (ii) Reactive Blue 2 & $6 \cdot 2$ & $149 \cdot 0$ & $23 \cdot 9$ & $85 \cdot 5$ & $25 \cdot 5$ \\
\hline (iii) Gel filtration & 1.6 & $132 \cdot 0$ & $83 \cdot 2$ & $75 \cdot 7$ & 88.5 \\
\hline (iv) Mono Q FPLC & $0 \cdot 2$ & $68 \cdot 4$ & $326 \cdot 0$ & $39 \cdot 3$ & $346 \cdot 0$ \\
\hline
\end{tabular}

* See Methods for details; purification was repeated three times with similar results.

† The specific activity of $326 \mathrm{nkat}$ ( $\mathrm{mg}$ protein) ${ }^{-1}$ obtained in the oxidative deamination assay corresponds to $682 \mathrm{nkat}$ (mg protein) ${ }^{-1}$ obtained in the reductive amination assay.

$25 \mathrm{mM}$ valine ( $\mathrm{N}$ source), the enzyme activities were $0 \cdot 27$ and 0.53 nkat $\mathrm{mg}^{-1}$, respectively. In these media, growth of $S$. fradiae, defined as $\mathrm{mg}$ cell protein per $\mathrm{ml}$ culture broth, was about four- to fivefold lower than that in glucose-valine medium.

\section{Purification of VDH2}

Mycelium grown for $72 \mathrm{~h}$ with $25 \mathrm{mM}$ L-valine plus $0.3 \%$ (w/v) enzymically hydrolysed casein as the $\mathrm{N}$ source was used as a source of VDH2 for purification. Preliminary experiments showed that the enzyme activity and stability in buffer $\mathrm{B}$ ( $\mathrm{pH} \mathrm{6.3)} \mathrm{were} \mathrm{similar} \mathrm{to} \mathrm{those} \mathrm{in} \mathrm{buffer} \mathrm{A}$
(pH 7.4). However, the enzyme lost $90 \%$ of its activity when stored in either buffer for $24 \mathrm{~h}$ at $4{ }^{\circ} \mathrm{C}$ without 2mercaptoethanol and glycerol. VDH2 bound to PhenylSepharose in the presence of $1.2 \mathrm{M} \mathrm{KCl}$ but unlike VDH1, it could not be eluted by decreasing the salt concentration (Vančura et al., 1988b). Affinity chrómatography on a Reactive-Blue 2 Sepharose column could be used as the first purification step. The enzyme weakly bound to the affinity matrix at $\mathrm{pH} 6.3$ and was eluted by increasing the $\mathrm{pH}$ of the buffer to $7 \cdot 5$, resulting in a $25 \cdot 5$-fold purification (Table 1). Other contaminant proteins were separated from VDH2 by subsequent purification steps, including gel filtration on a Sephacryl-S300 HR column and Mono Q FPLC (Fig. 1b). Overall, the enzyme was purified 346- 
Table 2. Substrate specificity for oxidative deamination by VDH2 and VDH1 from $S$. fradiae

\begin{tabular}{|lcc|}
\hline $\begin{array}{l}\text { Substrate } \\
(\mathbf{1 0} \mathbf{~ m M})^{*}\end{array}$ & $\begin{array}{c}\text { Relative activity } \\
\text { (\%) } \dagger\end{array}$ \\
\cline { 2 - 3 } & VDH2 & VDH1 $\ddagger$ \\
\hline Valine & 100 & 100 \\
Norvaline & 96.0 & $98 \cdot 0$ \\
2-Aminobutyrate & $158 \cdot 0$ & $68 \cdot 9$ \\
Leucine & 24.0 & 24.5 \\
Norleucine & 34.5 & $51 \cdot 5$ \\
Isoleucine & 22.0 & $29 \cdot 4$ \\
Alanine & $8 \cdot 3$ & $14 \cdot 7$ \\
\hline
\end{tabular}

* All amino acids were L-isomers; no activity was observed with Dvaline, or with glycine, threonine, serine, cysteine, glutamate, aspartate, asparagine, arginine, DL-phenylalanine, histidine or tryptophan.

† $\mathrm{VDH} 2$ relative activity of $100 \%$ corresponds to a specific activity of $326 \mathrm{nkat}$ ( $\mathrm{mg}$ protein) ${ }^{-1}$ obtained in the oxidative deamination assay. The data are the means of three measurements; standard deviations were all within $5 \%$ of the means.

$\ddagger$ Data from Vančura et al. (1988b).

fold with a yield of $39 \cdot 3 \%$ (Table 1 ) to homogeneity as judged by SDS-PAGE (Fig. 1b).

The purified enzyme was stable when stored in buffer $\mathrm{A}$ at $4{ }^{\circ} \mathrm{C}$ for $48 \mathrm{~h}$, but it lost $90 \%$ of its activity within $24 \mathrm{~h}$ when stored at $-20^{\circ} \mathrm{C}$ in buffer A containing $30 \%(\mathrm{v} / \mathrm{v}$ ) glycerol.

\section{Molecular mass and structure}

The $M_{\mathrm{r}}$ of the purified VDH2 was determined to be 80000 by gel filtration and 41000 under denaturing conditions by SDS-PAGE (Fig. 1b). These data suggest that the enzyme is composed of two identical subunits.

\section{pH and temperature optima}

VDH2 exhibited maximum oxidative deamination of $\mathrm{L}_{\text {- }}$ valine at $\mathrm{pH} 10.4$ in $0.3 \mathrm{M}$ glycine $/ \mathrm{KCl} / \mathrm{KOH}$ buffer. The $\mathrm{pH}$ optimum for the reductive amination of 2 ketoisovalerate in $0.3 \mathrm{M}$ Tris/ $\mathrm{HCl}$ buffer was $\mathrm{pH} 8.8$. At the $\mathrm{pH}$ optima, the amination rate was twice the deamination rate. The optimum temperature for VDH2 activity was $65^{\circ} \mathrm{C}$ for both oxidative deamination and reductive amination.

\section{Substrate specificity}

VDH2 catalysed oxidative deamination of a number of branched- and straight-chain amino acids (Table 2). L-2aminobutyrate (relative activity $158 \%$ ) was the preferred substrate, followed by L-valine $(100 \%)$ and L-norvaline $(96 \%)$, while the corresponding values of VDH1 were $68.9,100$, and $98 \%$ (Table 2). Lower activities were
Table 3. Substrate specificity for reductive amination by VDH2 and VDH1 from S. fradiae

\begin{tabular}{|lcc|}
\hline Substrate (10 $\mathbf{~ m M})$ & $\begin{array}{c}\text { Relative activity } \\
(\%) *\end{array}$ \\
\cline { 2 - 3 } & VDH2 & VDH1 $\dagger$ \\
\hline 2-Ketoisovalerate & 100 & 100 \\
2-Ketobutyrate & 100 & $78 \cdot 0$ \\
2-Ketoisocaproate & $20 \cdot 0$ & 20.0 \\
2-Keto-3-methyl- $n$-valerate & 16.6 & 23.2 \\
Pyruvate & 23.3 & 31.6 \\
\hline
\end{tabular}

* No activity was observed with 2-ketoglutarate or oxalacetate. VDH2 relative activity of $100 \%$ corresponds to a specific activity of 682 nkat (mg protein $)^{-1}$ obtained in the reductive amination assay. The data are the means of three measurements. Standard deviations were all within $5 \%$ of the means.

† Data from Vančura et al. (1988b).

obtained with L-norleucine, L-isoleucine, L-leucine and Lalanine.

The reductive amination activity with 2-ketobutyrate was similar to that with 2-ketoisovalerate. Lower activities were found with other keto acids (Table 3). No amination activity was observed when $\mathrm{NH}_{4}^{+}$was replaced with Tris $/ \mathrm{HCl}$, hydroxylamine or ethylamine.

The $K_{\mathrm{m}}$ values of the purified VDH2 were as follows: L-valine, $0.43 \mathrm{mM}$; NAD ${ }^{+}, 0.04 \mathrm{mM} ; \mathrm{NH}_{4}^{+}, 25.6 \mathrm{mM}$; 2-ketoisovalerate, $0.31 \mathrm{mM}$; and $\mathrm{NADH}, 0.028 \mathrm{mM}$. Catalytic properties of VDHs from various Streptomyces species are shown in Table 4 . The $K_{\text {eat }} / K_{\mathrm{m}}$ values of the oligomeric VDHs are much higher than those of the dimeric enzymes (Table 4).

\section{Coenzyme specificity}

VDH2 required $\mathrm{NAD}^{+}$as a specific natural cofactor for the oxidative deamination of L-valine; no activity was observed with $\mathrm{NADP}^{+}$. The enzyme activities with deamino-NAD ${ }^{+}$and 3-pyridinealdehyde-NAD ${ }^{+}$were 124 and $47.2 \%$ of those with $\mathrm{NAD}^{+}$, respectively, whereas the corresponding values of VDH1 were 63.9 and $0 \%$, although both enzymes exhibited similar activities with other $\mathrm{NAD}^{+}$analogues (Table 5). No reductive amination activity was found when NADH was replaced with NADPH.

\section{Inhibitors}

$\mathrm{VDH} 2$ activity was reduced to 0 and $30 \%$ by the - $\mathrm{SH}$ group inhibitors, iodoacetamide $(1 \mathrm{mM})$ and $p$-hydroxymercuribenzoate $(0.01 \mathrm{mM})$, respectively, indicating that sulfhydryl groups are necessary. However, the enzyme activity was not significantly affected by $1 \mathrm{mM}$ ATP, ADP, AMP, $\mathrm{Mg}^{2+}, \mathrm{Ca}^{2+}, \mathrm{Mn}^{2+}, \mathrm{Zn}^{2+}$ and citric acid cycle intermediates. $\mathrm{Cu}^{2+}(1 \mathrm{mM})$ exerted a $35.5 \%$ inhibition. When 20 or $50 \mathrm{mM}$ L-valine was used instead of 
Table 4. Catalytic properties of VDHs from various Streptomyces species

\begin{tabular}{|c|c|c|c|c|c|c|c|c|c|}
\hline \multirow[t]{2}{*}{ Species } & \multicolumn{2}{|c|}{ pH optimum } & \multicolumn{5}{|c|}{$K_{m}(m M)$} & \multirow{2}{*}{$\begin{array}{c}K_{\mathrm{cat}} / K_{\mathrm{m}} \\
\left(\mathrm{s}^{-1} \mathrm{mmol}^{-1} \mathrm{1}^{-1}\right)^{*} \\
\text { Valine }\end{array}$} & \multirow[t]{2}{*}{ Reference } \\
\hline & Deamination & Amination & Valine & $\mathbf{N A D}^{+}$ & $\mathbf{N H}_{4}^{+}$ & 2-KIV & NADH & & \\
\hline S. coelicolor & $10 \cdot 5$ & $9 \cdot 0$ & $10 \cdot 0$ & $0 \cdot 17$ & - & 0.6 & 0.093 & $2 \cdot 2$ & $\begin{array}{l}\text { Navarrete } \text { et al. } \\
\text { (1990) }\end{array}$ \\
\hline S. cinnamonensis & $10 \cdot 0$ & $9 \cdot 5$ & $1 \cdot 3$ & $0 \cdot 18$ & $55 \cdot 0$ & 0.8 & 0.074 & $21 \cdot 8$ & $\begin{array}{l}\text { Priestley \& } \\
\text { Robinson (1989) }\end{array}$ \\
\hline S. aureofaciens & $10 \cdot 7$ & $9 \cdot 0$ & $2 \cdot 5$ & $0 \cdot 1$ & $18 \cdot 2$ & $1 \cdot 25$ & 0.023 & 4814 & $\begin{array}{l}\text { Vančurová et al. } \\
\text { (1988) }\end{array}$ \\
\hline \multicolumn{10}{|l|}{ S. fradiae } \\
\hline VDH1 & $10 \cdot 6$ & $8 \cdot 8$ & $1 \cdot 0$ & 0.029 & $22 \cdot 0$ & 0.8 & 0.05 & 175246 & $\begin{array}{l}\text { Vančura et al. } \\
\text { (1988b) }\end{array}$ \\
\hline $\mathrm{VDH} 2$ & $10 \cdot 4$ & $8 \cdot 8$ & 0.43 & 0.04 & $25 \cdot 6$ & 0.31 & 0.028 & $60 \cdot 6$ & This paper \\
\hline
\end{tabular}

* Data were calculated from published specific activities and $K_{\mathrm{m}}$ with $\mathrm{L}$-valine, and the enzyme $M_{\mathrm{r}}$ values determined by gel filtration. 2-KIV, 2-ketoisovalerate; -, not reported.

Table 5. Coenzyme specificity of VDH2 and VDH1 from S. fradiae

\begin{tabular}{|c|c|c|}
\hline \multirow[t]{2}{*}{ Coenzyme $(2.5 \mathrm{mM}) *$} & \multicolumn{2}{|c|}{$\begin{array}{c}\text { Relative activity } \\
(\%) \dagger\end{array}$} \\
\hline & VDH2 & VDH1 \\
\hline $\mathrm{NAD}^{+}$ & 100 & 100 \\
\hline $\mathrm{NADP}^{+}$ & 0 & $10 \cdot 8$ \\
\hline $1, \mathrm{~N}^{6}$-Etheno-NAD ${ }^{+}$ & $70 \cdot 5$ & $64 \cdot 4$ \\
\hline Thionicotinamide- $\mathrm{NAD}^{+}$ & 0 & 0 \\
\hline Deamino-NAD ${ }^{+}$ & $124 \cdot 0$ & 63.9 \\
\hline$\alpha-\mathrm{NAD}^{+}$ & $5 \cdot 8$ & $3 \cdot 6$ \\
\hline 3-Pyridinealdehyde-NAD ${ }^{+}$ & $47 \cdot 2$ & 0 \\
\hline Deamido-NAD ${ }^{+}$ & 0 & 0 \\
\hline
\end{tabular}

* The assay with coenzyme analogues measured an increase in absorbance at the following wavelengths : thionicotinamide-NAD ${ }^{+}$, $395 \mathrm{~nm} \quad\left(\varepsilon 11.3 \times 10^{3} \mathrm{M}^{-1} \mathrm{~cm}^{-1}\right)$; deamino-NAD ${ }^{+}, \quad 338 \mathrm{~nm}$ $\left(\varepsilon 6.2 \times 10^{3} \mathrm{M}^{-1} \mathrm{~cm}^{-1}\right)$; 3 -pyridinealdehyde-NAD ${ }^{+}, \quad 358 \mathrm{~nm}$ $\left(\varepsilon 9.3 \times 10^{3} \mathrm{M}^{-1} \mathrm{~cm}^{-1}\right.$ ) (Ohshima et al., 1978). With other $\mathrm{NAD}^{+}$ analogues, the increase of absorbance at $340 \mathrm{~nm}$ was measured. The reaction was performed at $\mathrm{pH} 9 \cdot 5$ to avoid degradation of $\mathrm{NAD}^{+}$ analogues at higher values.

† VDH2 relative activity of $100 \%$ was 208 nkat $(\mathrm{mg} \text { protein })^{-1}$ obtained in the oxidative deamination assay. The data are the means of three measurements; standard deviations were all within $5 \%$ of the means.

$\ddagger$ Data from Vančura et al. (1988b).

$10 \mathrm{mM} \mathrm{L}$-valine in the standard reaction mixture, the enzyme activity was reduced by 22 or $40 \%$, respectively.

\section{DISCUSSION}

VDH activity in the tylosin-producing $S$. fradiae was previously thought to be associated with the 12 subunit VDH1, purified from strain 30/3 (Vančura et al., 1988b).
Our attempts to detect the enzyme from a sporulating isolate of this strain grown in similar media unexpectedly failed. Inactivation of VDH1 during native-PAGE is unlikely because the enzyme is relatively stable (Vančura et al., 1988b). The absence of VDH1 is probably not caused by a change in the composition of the medium since we could not detect the enzyme in cells grown with several $\mathrm{C}$ and $\mathrm{N}$ sources. It is also unlikely that mycelium from mixed bald and white strains, defective in aerial mycelium formation and sporulation, respectively, was used in the previous purification of VDH1 (Vančura et al., 1988b). Therefore, it appears that the expression of VDH1 in $S$. fradiae is unstable.

Instead of VDH1, we found the dimeric enzyme VDH2 as the only active VDH in $S$. fradiae (Fig. 1a). The result strongly suggests that $\mathrm{VDH} 2$ rather than $\mathrm{VDH} 1$ plays a role in metabolism of branched-chain amino acids and thus in tylosin biosynthesis. Ammonium is a strong repressor but $\mathrm{L}$-valine acts as an inducer of VDH2 even in the presence of ammonium ions, suggesting a catabolic function for the enzyme. This is supported by the isolation of prototrophic $S$. fradiae mutants lacking VDH activity (Omura et al., 1983a); also, valine transaminase (transaminase B) activity was detected (Vančura et al., 1988a, 1989). The $S$. coelicolor VDH activity is also strongly induced by valine and repressed by ammonia and glucose (Navarrete et al., 1990). However, the S. aureofaciens enzyme is not significantly repressed by ammonia (Vančurová et al., 1988).

Whether the $S$. fradiae VDH activity is regulated by glucose, as is the $S$. coelicolor enzyme (Navarrete et al., 1990), is unclear because VDH activity in $S$. fradiae cells grown in medium containing $100 \mathrm{mM} \mathrm{L}$-valine as both the $\mathrm{C}$ and $\mathrm{N}$ source, or in glycerol-valine medium was threeto fivefold lower than in cells grown in glucose-valine. Poor growth of $S$. fradiae in these media, probably due to the absence of a readily assimilable $C$ source, may lower the synthesis of VDH2, even though transcription of $v d h$ is derepressed (Navarrete et al., 1990). 
Affinity chromatography on Reactive-Blue 2 Sepharose is the essential step in the 3-step purification of the dimeric $\mathrm{VDH} 2$ from $S$. fradiae. Previous attempts to purify dimeric VDHs from S. cinnamonensis (Priestley \& Robinson, 1989) and S. coelicolor (Navarrete et al., 1990) by affinity chromatography were unsuccessful, probably due to the instability of the enzymes at low $\mathrm{pH}$ values. The $S$. fradiae enzyme was stable and bound efficiently to Reactive-Blue 2 Sepharose at $\mathrm{pH} \mathrm{6.3} \mathrm{and} \mathrm{it} \mathrm{was} \mathrm{readily} \mathrm{eluted} \mathrm{by}$ increasing the $\mathrm{pH}$ of the buffer to $7 \cdot 5$. The simple and effective purification procedure described here makes it possible to rapidly obtain large quantities of pure VDH, which could be used for enzyme crystallization and threedimensional structure analysis.

VDH2, with two subunits each of $M_{r} 41000$, is similar to the enzymes from $S$. cinnamonensis (Priestley \& Robinson, 1989), S. coelicolor (Navarrete et al., 1990) and Alcaligenes faecalis (Ohshima \& Soda, 1993). However, it is significantly different from the $S$. fradiae VDH1, composed of twelve subunits, each of $M_{\mathrm{r}} 18000$ (Vančura et al., 1988b), and from the $S$. aureofaciens enzyme, composed of four subunits, each of $M_{\mathrm{r}} 29000$ (Vančurová et al., 1988). Navarrete et al. (1990) reported that the $S$. fradiae crude extract contained a protein that cross-reacted with polyvalent antibodies raised against $S$. coelicolor $\mathrm{VDH}$. This protein was probably the VDH2 described here.

In the absence of a reducing substance such as 2mercaptoethanol, the oligomeric VDHs are relatively stable (Vančura et al., 1988b; Vančurová et al., 1988), whereas dimeric VDHs are inactivated (Priestley \& Robinson, 1989; Navarrete et al., 1990; this paper). Therefore, it is likely that the oligomeric structures provide better protection of the - $\mathrm{SH}$ groups from oxidation.

VDH2 differs significantly from the Bacillus leucine dehydrogenases (LDHs, EC 1.4.1.9) composed of six to eight subunits, each of $M_{\mathrm{r}}$ ranging from 39000 to 49000 (Ohshima et al., 1978; Kärst et al., 1989). Although the amino acid sequence of the VDH polypeptide of $M_{\mathrm{r}}$ 41000 shows a 55-60\% identity with that of LDHs from Bacillus (Tang \& Hutchinson, 1993), L-2-aminobutyrate and L-valine are the preferred substrates for the dimeric VDHs, whereas L-leucine is the preferred substrate for LDHs. Moreover, the dimeric VDHs differ from LDHs in coenzyme specificity (Ohshima et al., 1978; this paper), amino acid composition and immunochemical properties (Ohshima \& Soda, 1993).

Despite the differences in structure between VDH2 and the other dehydrogenases of Streptomyces, there is no marked difference in $\mathrm{pH}$ and temperature optima for enzyme activity, and $K_{\mathrm{m}}$ values for the main substrates. However, there is a fivefold higher $K_{\mathrm{m}}$ for L-valine in $S$. coelicolor and a twofold higher $K_{\mathrm{m}}$ for ammonia in $S$. cinnamonensis (Table 4). VDHs with more subunits have markedly increased catalytic efficiencies $\left(K_{\text {cat }} / K_{\mathrm{m}}\right.$ values $)$ (Table 4). Like the other dimeric VDHs, the $S$. fradiae VDH2 exhibited high activity with L-2-aminobutyrate $(158 \%)$. This property clearly distinguishes the dimeric enzymes from the oligomeric enzymes (Vančura et al., 1988b; Vančurová et al., 1988). Among several metabolites tested, only L-valine at concentrations higher than $20 \mathrm{mM}$ partially inhibited VDH2 activity; hence, it may be involved in regulating the enzyme activity in vivo, as suggested for S. coelicolor VDH (Navarrete et al., 1990). The increased activity of VDH2 with deamino-NAD ${ }^{+}$ suggests that the amino group in the adenine moiety of $\mathrm{NAD}^{+}$is not essential, and can partially interfere with binding of $\mathrm{NAD}^{+}$to the enzyme.

The results of the enzyme characterization show that VDH2 is different from VDH1 in enzyme stability, subunit size, native enzyme structure, and substrate and coenzyme specificities. The isolation of dimeric VDHs from $S$. fradiae as well as $S$. cinnamonensis and $S$. coelicolor indicate that these enzymes are widely distributed in Streptomyces. However, factors controlling expression of the dodecameric VDH1 remain to be defined. To address this question, we are currently looking for $S$. fradiae mutants exhibiting detectable VDH1 activities.

After this manuscript had been submitted, we learned that Tang et al. (1994) had cloned and sequenced the $v d b$ gene encoding VDH2 of $S$. fradiae. The deduced products of this gene and the partial $v d h$ gene of $S$. ambofaciens are very similar in their amino acid sequences to the deduced product of the $S$. coelicolor $v d h$ gene. Disruption of $v d b$ inhibits the biosynthesis of tylosin in S. fradiae and spiramycin in $S$. ambofaciens. The data suggest that $S$. fradiae and $S$. ambofaciens have only one $v d b$ gene responsible for VDH activity, consistent with our evidence that VDH2 is the only active VDH in $S$. fradiae.

\section{ACKNOWLEDGEMENTS}

The financial support from UNESCO and the Institute of Microbiology to L.T.N. and K.T.N. is gratefully acknowledged. We thank Drs J. Kopecký and J. Novotná for providing the strain, chemicals and chromatography facilities.

\section{REFERENCES}

Bradford, M. M. (1976). A rapid and sensitive method for the quantitation of microgram quantities of protein utilizing the principle of protein-dye binding. Anal Biochem 72, 248-254.

Hames, B. D. (1981). An introduction to polyacrylamide gel electrophoresis. In Gel Electrophoresis of Proteins: a Practical Approach, pp. 1-91. Edited by B. D. Hames \& D. Rickwood. London and Washington, DC: IRL Press.

Hutchinson, C. R. (1994). Drug synthesis by genetically engineered microorganisms. Bio/Technology 12, 375-380.

Kärst, U., Schutte, H., Baydoun, H. \& Tsai, H. (1989). Purification and characterization of leucine dehydrogenase from the thermophile 'Bacillus caldolyticus'. J Gen Microbiol 135, 1305-1313.

Laemmli, U. K. (1970). Cleavage of structural proteins during the assembly of the head of bacteriophage $\mathrm{T}_{4}$. Nature 227, 680-685.

Massey, L. M., Sokatch, J. R. \& Condrad, R. S. (1976). Branchedchain amino acid catabolism in bacteria. Bacteriol Rev 40, 42-54. 
Navarrete, R. M., Vara, J. A. \& Hutchinson, C. R. (1990). Purification of an inducible L-valine dehydrogenase of Streptomyces coelicolor A3(2). J Gen Microbiol 136, 273-281.

Ohshima, T. \& Soda, K. (1993). Valine dehydrogenase from a non spore-forming bacterium, Alcaligenes faecalis: purification and characterization. Biocbim Biophys Acta 1162, 221-226.

Ohshima, T., Misono, H. \& Soda, K. (1978). Properties of crystalline leucine dehydrogenase from Bacillus sphaericus. J Biol Chem 253, 5719-5725.

Omura, S. \& Tanaka, Y. (1986). Biosynthesis of tylosin and its regulation by ammonium and phosphate. In Regulation of Secondary Metabolite Formation, pp. 305-332. Edited by H. Kleinkauf, H. von Dohren, H. Dornauer \& G. Nesemann. Weinheim: VCH Verlagsgesellschaft.

Omura, S., Tanaka, Y., Mamada, H. \& Masuma, R. (1983a). Ammonium ion suppresses the biosynthesis of tylosin aglycone by interference with valine catabolism in Streptomyces fradiae. J Antibiot 36, 1792-1794.

Omura, S., Tsuzuki, K., Tanaka, Y., Sakakibara, H., Aizawa, M. \& Lukacs, J. (1983b). Valine as a precursor of the $n$-butyrate unit in the biosynthesis of macrolide aglycones. $J$ Antibiot 36, 614-616.

Posp(šil, S., Sedmera, P., Havránek, M., Krumphanzl, V. \& Vaněk, Z. (1983). Biosynthesis of monensins A and B. J Antibiot 36, 617-619.

Priestley, N. D. \& Robinson, J. A. (1989). Purification and catalytic properties of L-valine dehydrogenase from Streptomyces cinnamonensis. Biocbem J 261, 853-861.

Sherman, M. M., Yue, S. \& Hutchinson, C. R. (1986). Biosynthesis of lasalocid A. Metabolic interrelationships of carboxylic acid precursors and polyether antibiotics. $J$ Antibiot 39, 1135-1143.

Sood, G. R., Ashworth, D. M., Ajaz, A. A. \& Robinson, J. A. (1988).
Biosynthesis of the polyether antibiotic monensin A. Results from the incorporation of labeled acetate and propionate as a probe of the carbon chain assembly process. J Chem Soc Perkin Trans 1 1988, 3183-3194.

Tang, L. \& Hutchinson, C. R. (1993). Sequence, transcriptional, and functional analyses of the valine (branched-chain amino acid) dehydrogenase gene of Streptomyces coelicolor. J Bacteriol 175, 4176-4185.

Tang, L., Zhang, Y.-X. \& Hutchinson, C. R. (1994). Amino acid catabolism and antibiotic synthesis: valine is a source of precursors for macrolide biosynthesis in Streptomyces ambofaciens and Streptomyces fradiae. J Bacteriol 176, 6107-6119.

Vančura, A., Rezanka, T., Marł́salek, J., Melzoch, K., Basałová, G. $\&$ KYiY̌tan, V. (1988a). Metabolism of L-threonine and fatty acids and tylosin biosynthesis in Streptomyces fradiae. FEMS Microbiol Lett 49, 411-415.

Vančura, A., Vančurová, I., Volc, J., Fussey, S. P. M., Flieger, M., Neužil, J., Marš́lek, J. \& Běhal, V. (1988b). Valine dehydrogenase from Streptomyces fradiae : purification and properties. J Gen Microbiol 134, 3213-3219.

Vančura, A., Vanłưrová, I., Kopecký, J., Marłálek, J., Cikánek, D., Basałova, G. \& Kfistan, V. (1989). Regulation of branched-chain amino acid biosynthesis in Streptomyces fradiae, a producer of tylosin. Arcb Microbiol 151, 537-540.

Vančurová, I., Vančura, A., Volc, J., Neužil, J., Flieger, M., Basałova, G. \& Běhal, V. (1988). Isolation and characterization of valine dehydrogenase from Streptomyces aureofaciens. J Bacteriol 170, 5192-5196.

Received 6 October 1994; revised 17 January 1995; accepted 26 January 1995. 